those methods of open discussion and voluntary agreement which characterize the democratic State.

There is no distinction between the problems of morale in an industrial organization and those in any other organization or society. There are the daily problems of maintaining internal equilibrium, that is, of maintaining the kind of social organization in which individuals and groups working together can obtain human satisfactions that will make them willing to contribute their services to the economic objective of co-operation. There are the daily problems of diagnosing possible sources of interference, liquidating human tensions and strains among individuals and groups, helping people to orient themselves to their work groups, and detecting blockages in the channels of communications. These indeed are the very problems which tend to be overlooked, at least outside of the Armed Forces, under the stress of war, and without leaders skilled in diagnosing human situations we cannot preserve the social values which are so essential in a. cooperative system. Prof. Roethlisberger's book, with all its suggestiveness and practical hints, is by and large another exposition of the truth of the ancient proverb, "Where there is no wisdom the people perish". Nothing could more surely hasten the day of full victory than leadership which, from top to bottom, handled the human problems of production and organization-and reconstruction-with understanding, imaginative insight, and the same courage which marked the finest hours of the summer and autumn of 1940 .

\section{COSMOGONY AND RELIGION}

\section{The Beginning and End of the World}

Riddell Memorial Lectures, Fourteenth Series, delivered before the University of Durham at King's College, Newcastle-upon-Tyne, in February 1942. By Prof. Edmund Taylor Whittaker. Pp. 64. (London: Oxford University Press, 1942.) 2s. 6d. net. GVERY year the Riddell Trust arranges for a 1. course of lectures on "the relation between religion and contemporary development of thought". The Lectures for 1942 deal particularly with the relation between cosmogony and religion, and it is a matter for congratulation that the trustees have found a lecturer who is well-versed in both science and theology.

The greater part of the book consists of an exposition of the findings of astronomy and physies as to the beginnings and endings of the universe. This is admirably done, and would suffice by itself to make the book one of outstanding merit. Yet most readers will be mainly interested to see what Prof. Whittaker has to say on its religious implications. He tells us that the purpose of his lectures is to maintain the doctrine "that God, the first cause and last end of all things, can, from created things, be known with certainty by the natural light of human reason". From the evidence of science that the world is of finite duration in time, he deduces an argument against pantheism -if God were Nature and Nature God, then it would be necessary for God to be born and perish, which is absurd.

Apart from this, there is no sustained effort to discover God "from created things", or through any form of science. Whittaker holds that the influence of science on religion must be psychological rather than logical-new developments in science can never alter the Christian faith, but only man's receptivity to that faith. Here he is, of course, thinking of the immutable cast-iron faith of the Roman Church, rather than of the plastic faith of the liberal Anglican. This latter has often changed its shape (in so far as it has any shape) through the impact of new scientific truth-as, for example, through the recognition that our earth is not the physical centre of the universe, but a fragment which has become detached from a grain of sand in that vast swirling sand-storm we call space. With this in his mind, can the enlightened churchman of to-day be expected to hold, with his pre-Copernican ancestors, that the revelation to Moses on the mountain, or the birth of the Holy Child, were events of cosmical importance? Or, with Whittaker, that the Incarnation gave to this small planet the value of the universe, and to a narrow span of time the value of eternity? We wish that Prof. Whittaker could have discussed such questions, but he debars himself from so doing at the outset.

The reflection that "mankind appears for a brief space of time, a short instant in the duration of the stellar system, and then disappears" brings him to the age-old question: "Can the grand sum total of existence be so utterly futile as that ?" To this he replies that in the copepods, which exist in countless billions in the sea, the individual counts for nothing and the race is everything, but that when we come to man the race loses its importance and the individual life acquires the supreme value. "The goal of the whole process of evolution, the justifica. tion of creation, is the existence of human personality." But this, as Whittaker agrees, is a matter of "what it is reasonable to believe", and not of what science encourages us to believe. Species after species lived on earth for many millions of years before extermination befell it; there can be no scientific warrant for supposing that man, who has not yet survived his first million years, and seems already to be making a fair mess of things, is the final cul. mination of creation.

The plain fact seems to be that cosmogony has disappointingly little to say on religion. The two never make real contact, still less come to gripshow could they? "The things that are seen are temporal, but the things that are not seen are eternal." Cosmology may confirm the first half of the Apostle's dictum, but provides too narrow a platform for the discussion of the second half. Science can speak with philosophy, and philosophy with religion, but attempts to short-circuit philosophy have usually failed, and perhaps must always fail; the universe does not carry its secrets written on its sleeve.

J. H. Jeans.

\section{BRADLEY'S DIALECTIC}

\section{Bradley's Dialectic}

By Dr. Ralph Withington Church. Pp. 189. (London : George Allen and Unwin, Ltd., 1942.) 10s. 6d. net..

7 HERE is real satisfaction for a lifelong student of philosophy, when he finds the loyalties of his youth emerging from obloquy and arresting the attention of a generation whose temper of mind is inevitably alien to bis own. It is thus at the present 